\title{
Choreiform Movement Disorder Associated with Subdural Hematoma: A Case Report
}

\author{
Subdural Hematoma Bağlı Koreiform Hareket Bozukluğu Bir Olgu Sunumu
}

Keywords: Chorea, craniocerebral trauma, subdural hematoma

Anahtar Kelimeler: Kore, kraniyoserebral travma, subdural hematom

\section{Dear Editor,}

A 68-year-old female was admitted to our clinic with headache and involuntary curling-like movements involving the right upper and lower extremities and trunk, which suddenly started 4 days ago and progressed. These movements were lasting 3-4 seconds and recurring in every 4 seconds. There was no history of trauma or anything else in her medical history. She was conscious, orientated, and cooperated. There was no neck stiffness and cranial nerves were intact. Cerebellar tests were normal, muscle strength was $5 / 5$ in all extremities, Babinski signs were negative bilaterally, and deep tendon reflexes were normoactive. There were choreiform movements involving the right arm and leg. Fasting blood glucose, electrolytes, liver function tests, thyroid function tests, hemogram, complete urine analysis, and urine microscopy resulted as normal. Creatinine was $0.56 \mathrm{mg} / \mathrm{dL}$, prothrombin time was $18.8 \mathrm{~s}$, INR was 1.42 , and the erythrocyte sedimentation rate was $30 \mathrm{~mm} / \mathrm{h}$. Cranial magnetic resonance imaging (MRI) with sagittal T2 fast spin echo (FSE), axial T2 FSE, axial T1 fluid-attenuated inversion recovery (FLAIR) and coronal T2 FLAIR sequences were performed. Neuroimaging showed enlarged and deepened bilateral Sylvian fissures and hemispheric cortical sulci, which were suggestive of cerebral cortical atrophy. A smoothlycontoured septum pellucidum cyst that was approximately $18 \mathrm{~mm}$ at the widest point was seen hypointense in T1A and hyperintense in T2A-weighted images in the vicinity superior of the third ventricle. A lesion in the right fronto-parietal subdural area, which was seen hyperintense in all MRI sequences and which was approximately $32 \mathrm{~mm}$ at the widest point, suggested a subdural hematoma (SDH) (Figure 1). After evaluation of the cranial MRI, the patient was asked if she had had any trauma and she admitted that she had a head trauma 4 days ago. With the data gathered from anamnesis, neurologic examination, laboratory tests, and cranial MRI, a diagnosis of subacute SDH due to the trauma was considered and a surgical operation was planned by the neurosurgery department.

Patients with SDH could be asymptomatic or could present with loss of consciousness due to acute bleeding, hemiparesis or coma. Seizure and headache are the other common findings of $\mathrm{SDH}(1,2)$. Choreiform movement disorder caused by $\mathrm{SDH}$ was first reported in a child with leukemia in 1977 (3). Neuroimaging has a crucial role in the diagnosis of SDH. Computed tomography, cranial MRI, and diffusion MRI are neuroimaging modalities that are used in diagnosis of SDH (1). Clinically stable patients who have a bleed less than $5 \mathrm{~mm}$ in diameter could be followed up for spontaneous resolution. Surgery is advised in clinically unstable patients, patients with 9 or more points in the Glasgow Coma Scale (GCS), patients with a more than 2 points increase in GCS after admission, patients with $>10 \mathrm{~mm}$ thickness of clot or with $>5 \mathrm{~mm}$ shift (4). Craniectomy with membranectomy and single or double"Burr hole" drainage are the surgical procedures used in the treatment of $\mathrm{SDH}(1,5)$. The superiority of one method over another is controversial. Right frontal "Burr hole" drainage was performed and the patient's involuntary movements improved in the postoperative period. The patient was discharged and

\footnotetext{
Address for Correspondence/Yazışma Adresi: Ahmet Özşimşek MD, Usak Medical Park Hospital, Clinic of Neurology, Usak, Turkey Phone: +90 5068884718 E-mail: ahmet.ozsimsek@yahoo.com.tr ORCID ID: orcid.org/0000-0003-0696-6749 Received/Geliş Tarihi: 11.04.2017 Accepted/Kabul Tarihi: 24.07.2017

${ }^{\circ}$ Copyright 2018 by Turkish Neurological Society Turkish Journal of Neurology published by Galenos Publishing House.
} 

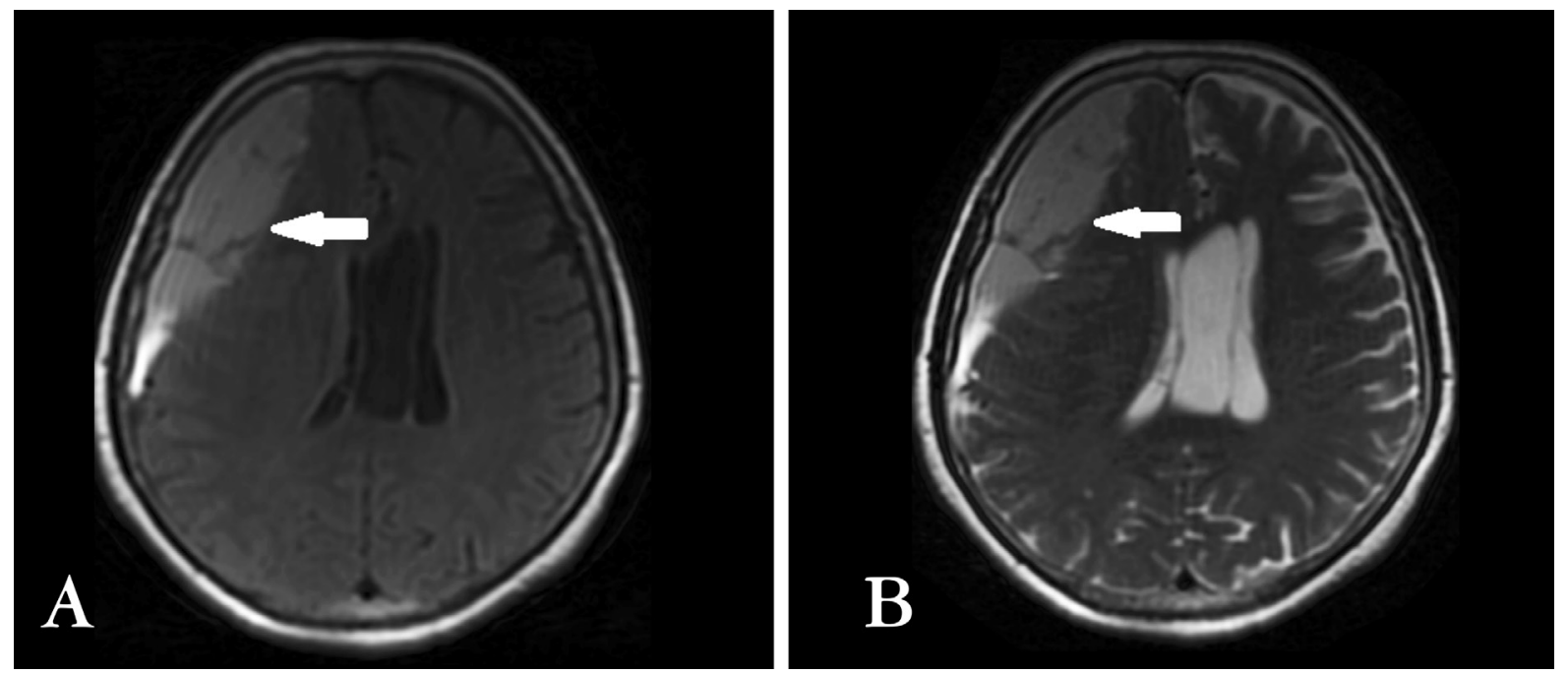

Figure 1. A) T1 axial section magnetic resonance image, B) T2 axial section magnetic resonance image

followed up. As a result, SDH could rarely result in choreiform movements and these movements could totally improve with treatment of the $\mathrm{SDH}$.

\section{Ethics}

Informed Consent: The patient gave informed consent.

Peer-review: Internally peer-reviewed.

Financial Disclosure: No financial support.

\section{References}

1. Tripathy SR, Swarnakar PK, Mishra S, Mishra SS, Dhir MK, Behera SK, Nath PC, Jena SP, Mohanta I, Das D, Satapathy MC, Rout SK, Behera BR, Parida DK, Rath TS. A review of subacute subdural hematoma (SASDH) with our institutional experience and its management by double barrel technique (DbT): A novel technique. Surg Neurol Int 2016;7(Suppl 28):767-774.

2. Kpelao E, Beketi KA, Moumouni AK, Doleagbenou A, Ntimon B, Egbohou P, Mouzou T, Tomta K, Sama DH, Abalo A, Walla A, Dossim A. Clinical profile of subdural hematomas: dangerousness of subdural subacute hematoma. Neurosurg Rev 2016;39:237-240.

3. Bean SC, Ladisch S. Chorea associated with a subdural hematoma in a child with leukemia. J Pediatr 1977;90:255-256.

4. Bullock MR, Chesnut R, Ghajar J, Gordon D, Hartl R, Newell DW, Servadei F, Walters BC, Wilberger JE; Surgical Management of Traumatic Brain Injury Author Group. Surgical management of acute subdural hematomas. Neurosurgery 2006;58(Suppl 3):16-24.

5. Kansal R, Nadkarni T, Goel A. Single versus double burr hole drainage of chronic subdural hematomas. A study of 267 cases. J Clin Neurosci 2010;17:428-429 